\title{
Cycling of a Quinone-Bromide Flow Battery for Large-Scale Electrochemical Energy Storage
}

\section{Citation}

Huskinson, B., M. P. Marshak, M. R. Gerhardt, and M. J. Aziz. 2014. “Cycling of a QuinoneBromide Flow Battery for Large-Scale Electrochemical Energy Storage." ECS Transactions 61 (37) (September 29): 27-30. doi:10.1149/06137.0027ecst.

\section{Published Version}

doi:10.1149/06137.0027ecst

\section{Permanent link}

http://nrs.harvard.edu/urn-3:HUL.InstRepos:25984767

\section{Terms of Use}

This article was downloaded from Harvard University's DASH repository, and is made available under the terms and conditions applicable to Open Access Policy Articles, as set forth at http:// nrs.harvard.edu/urn-3:HUL.InstRepos:dash.current.terms-of-use\#OAP

\section{Share Your Story}

The Harvard community has made this article openly available.

Please share how this access benefits you. Submit a story.

\section{Accessibility}


Published as ECS Transactions 61, 27 (2014).

\title{
Cycling of a Quinone-Bromide Flow Battery for Large-Scale Electrochemical Energy Storage
}

\author{
Brian Huskinson, Michael P. Marshak, Michael R. Gerhardt, and Michael J. Aziz ${ }^{\mathrm{a}}$ \\ ${ }^{a}$ Harvard School of Engineering and Applied Sciences, Cambridge, Massachusetts 02138, \\ USA
}

\begin{abstract}
We have demonstrated the performance of an aqueous redox flow battery composed of a negative electrode consisting of a redox couple between anthraquinone di-sulfonate and its corresponding hydroquinone, and a positive electrode consisting of a redox couple between hydrobromic acid and bromine. The peak power density is approximately $0.6 \mathrm{~W} / \mathrm{cm}^{2}$. After 750 deep cycles, the average discharge capacity retention is $99.84 \%$ per cycle and the average current efficiency is $98.35 \%$.
\end{abstract}

The greatest technical hurdle to us getting most of our electricity from sunshine and wind is their intermittency. We recently published initial results on the performance of a quinone-bromide flow battery that appears particularly well suited to cost-effective storage of large amounts of electrical energy, e.g. from intermittent renewables (1). The negative electrolyte in the discharged state is composed of $100 \mathrm{ml}$ of an aqueous solution of $1 \mathrm{M}$ 9,10-anthraquinone-2,7-disulphonic acid (AQDS) and $1 \mathrm{M} \mathrm{H}_{2} \mathrm{SO}_{4}$. The positive electrolyte in the discharged state is composed $120 \mathrm{ml}$ of an aqueous solution of $3 \mathrm{M} \mathrm{HBr}$ and $0.5 \mathrm{M} \mathrm{Br}_{2}$. As described in Reference (1), six sheets of pre-treated Toray carbon paper, with no added catalyst, were used on either side of a Nafion 212 (50 um) membrane, using interdigitated flow fields. A schematic of the cell is shown in Figure 1. During charging, the quinone undergoes a rapid, reversible two-electron two-proton reduction to the corresponding hydroquinone, $\mathrm{AQDSH}_{2}$, and the bromide on the positive electrode is oxidized to bromine, accompanied by the migration of protons from posolyte to negolyte. During discharging, these reactions are reversed.

Polarization curves for several states of charge (SOC), reported in Reference (1), are reproduced in Figure 2. We take SOC to mean the quinone state of charge, i.e. the percentage of the organic molecules that are in the reduced form. The inset shows that the open-circuit potential varies approximately linearly with SOC and is about $0.80 \mathrm{~V}$ at $50 \%$ SOC and about $0.94 \mathrm{~V}$ at $100 \%$ SOC. These results imply a peak power density of about $0.6 \mathrm{~V}$ at $90 \%$ SOC (1).

The results of recent cycling tests are reported in this work. The cell was rebuilt with a Nafion 115 (125 um) membrane and cycled 106 times from near zero SOC to near $100 \%$ SOC by imposing a current density of $0.25 \mathrm{~A} / \mathrm{cm}^{2}$, monitoring the voltage, and automatically switching current direction when the voltage reached 0 or 1.5 Volts. The results are shown in Figure 3. The average discharge capacity retention per cycle, defined as the number of coulombs discharged in a particular cycle divided by the number of coulombs discharged in the immediately preceding cycle, was 99.986\%. 


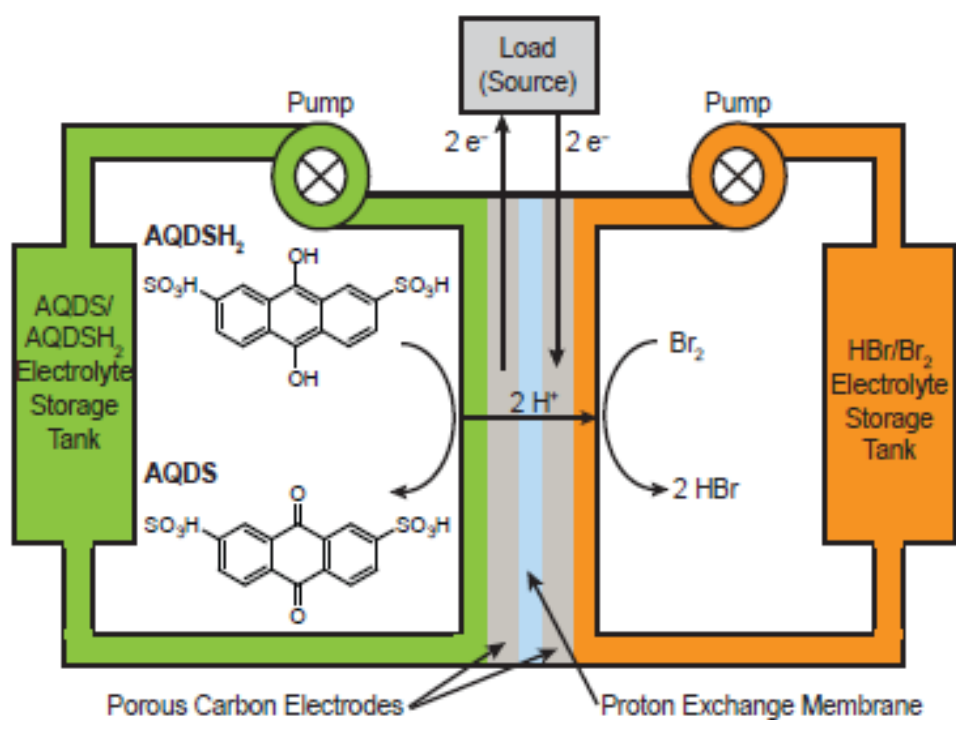

Figure 1. Cell schematic. The arrows indicate processes occurring in discharge or galvanic mode; for charge or electrolytic mode the arrows are reversed.

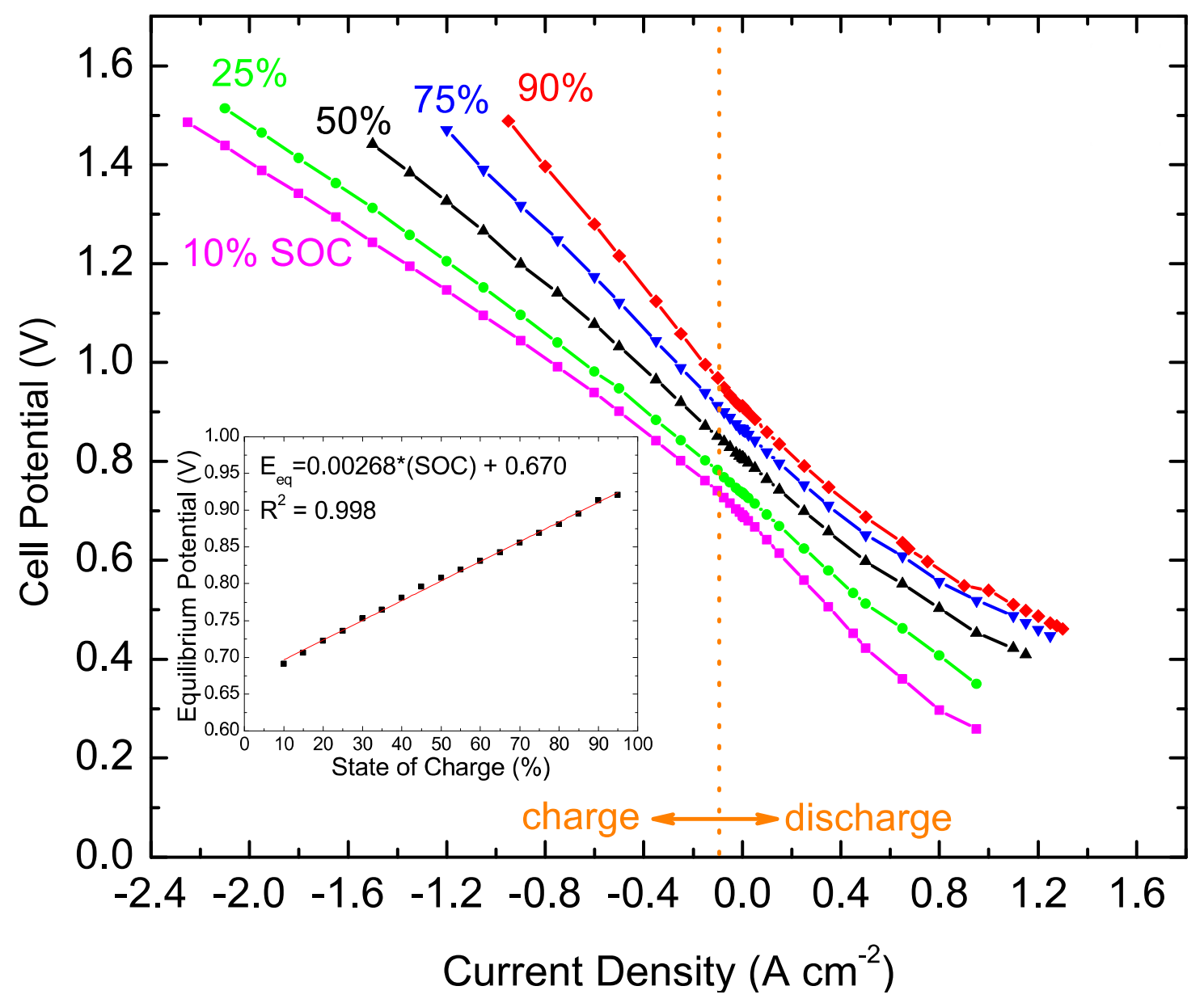

Figure 2. Cell voltage vs. current density with quinone state of charge as a parameter. Inset: open-circuit voltage vs. quinone state of charge. 

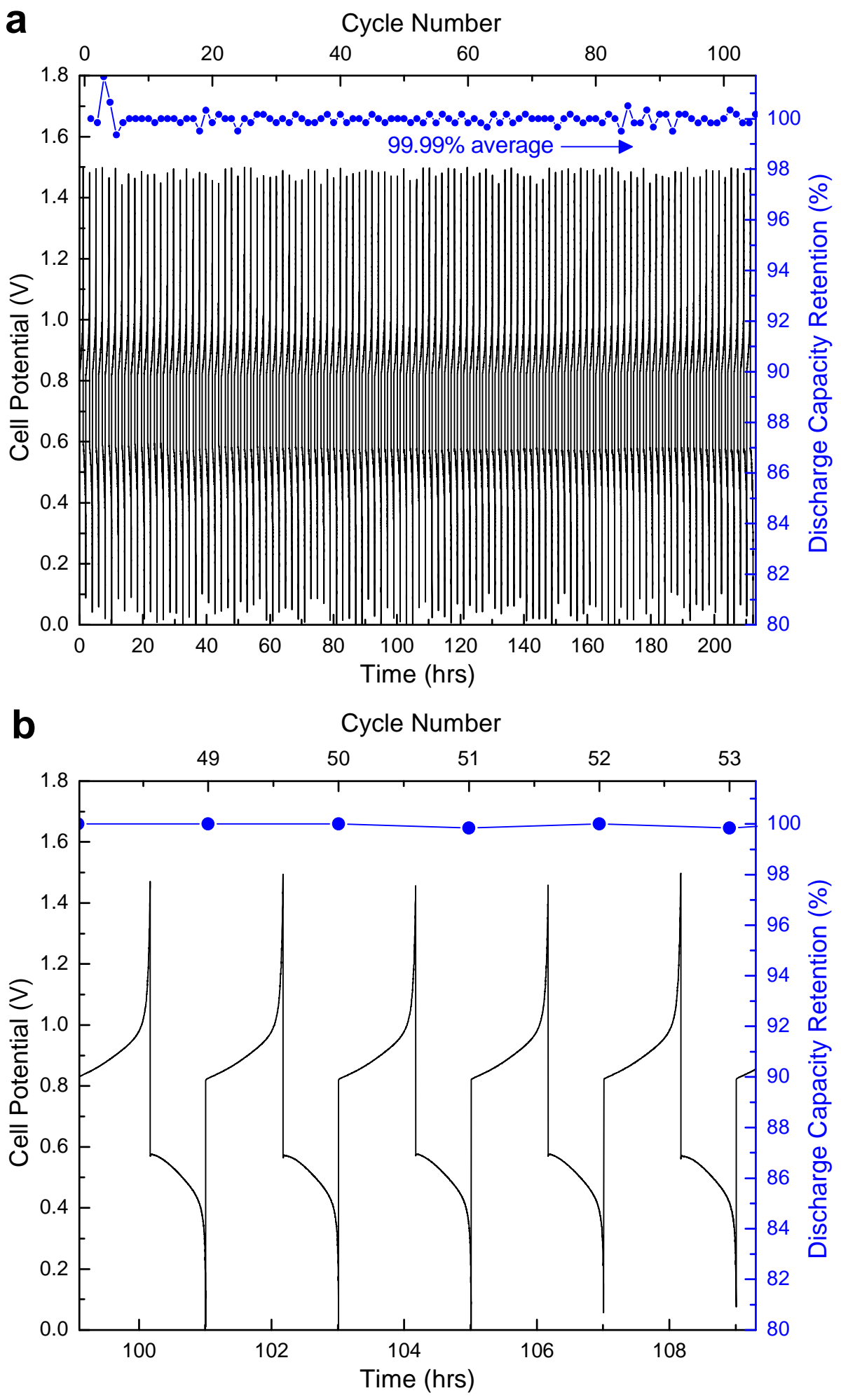

Figure 3. Results of 106 cycles of the AQDS-bromide flow battery at $\pm 0.25 \mathrm{~A} / \mathrm{cm}^{2}$ (a). In (b) is shown a zoomed-in subset of these cycles to highlight their shape. The average capacity retention per cycle was $99.986 \%$. 


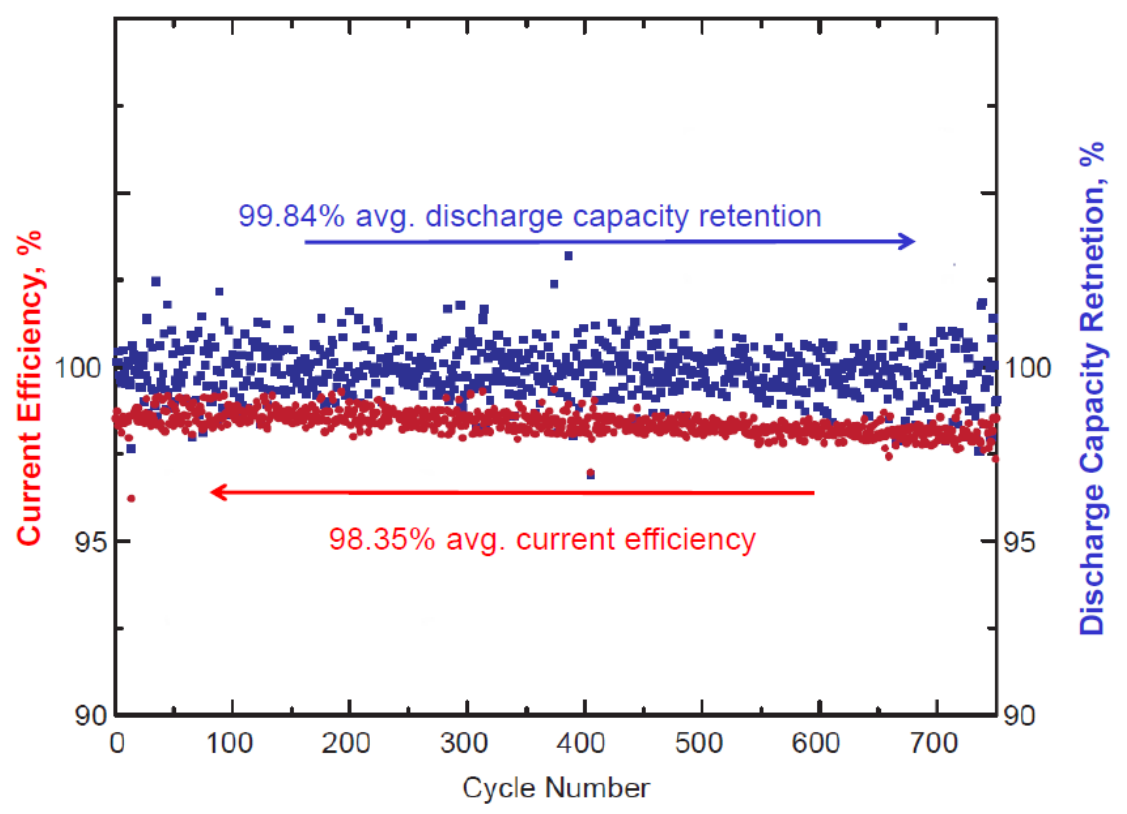

Figure 4. Results of 750 cycles of the AQDS-bromide flow battery at $\pm 0.75 \mathrm{~A} / \mathrm{cm}^{2}$.

The results from a cycling test at $0.75 \mathrm{~A} / \mathrm{cm}^{2}$ are shown in Figure 4. The average discharge capacity retention per cycle was $99.84 \%$. Additionally, we report the current efficiency, which we reckon as the number of coulombs discharged in a cycle divided by the number of coulombs input in the immediately preceding charging process. The average current efficiency is $98.35 \%$.

In ongoing work we are examining the mechanisms of capacity fade and current inefficiency.

\section{Acknowledgments}

This work was partially funded through the US Department of Energy ARPA-E Award DE-AR0000348 and partially funded through the Harvard School of Engineering and Applied Sciences. B.H. was supported in part by an NSF Graduate Research Fellowship. We acknowledge fruitful discussions with Qing Chen, Roy Gordon, Changwon Suh, Süleyman Er, Lauren Hartle, and Alán Aspuru-Guzik.

\section{References}

1. B. Huskinson, M.P. Marshak, C. Suh, S. Er, M.R. Gerhardt, C.J. Galvin, X. Chen, A. Aspuru-Guzik, R.G. Gordon and M.J. Aziz, Nature 505, 195 (2014), http://dash.harvard.edu/handle/1/11688785. 